AperTO - Archivio Istituzionale Open Access dell'Università di Torino

\title{
Housing inequality and social class in Europe
}

\section{This is a pre print version of the following article:}

Original Citation:

Availability:

This version is available http://hdl.handle.net/2318/147334

since 2016-07-25T17:50:42Z

Terms of use:

Open Access

Anyone can freely access the full text of works made available as "Open Access". Works made available under a Creative Commons license can be used according to the terms and conditions of said license. Use of all other works requires consent of the right holder (author or publisher) if not exempted from copyright protection by the applicable law. 
Home-ownership, poverty, and housing deprivation

\section{Marianna Filandri · Manuela Olagnero}

M. Filandri (mail)

Department of Sociology, University of Milan-Bicocca, Milan, Italy e-mail: marianna.filandri1@unimib.it

M. Filandri

Department of Culture, Politics and Society, University of Turin, Turin Italy

M. Olagnero

Department of Culture, Politics and Society, University of Turin, Turin, Italy

\section{FULL ADDRESS FOR CORRISPONDENCE}

Marianna Filandri

Dipartimento di Culture, Politica e Società

Lungo Dora Siena 100

10135 Torino, Italy

+00393476704103

+00390116702612

Manuela Olagnero

Dipartimento di Culture, Politica e Società

Lungo Dora Siena 100

10135 Torino, Italy

+00393476702680

+00390116702612 


\begin{abstract}
On the basis of Eu-Silc data, this paper conducts a comparative analysis of housing conditions in different European countries by focusing on housing deprivation. The variance in housing conditions taking into account tenure and housing cost could provide further insights about the relationship between poverty and housing deprivation in Europe. To support this claim, three main dimensions of inequality will be identified: tenure, poverty, and housing deprivation. A micro level data analysis was performed, in order to take account of individual and family costs of access and maintenance of home-ownership in settings and in periods (such as the present day) of rising housing prices and of decreasing income resources in terms of amount and stability. The aim is thus to demonstrate that for many European households there is a trade off between being poor and living in housing deprivation and this is true for both owners and non-owners.
\end{abstract}

Keywords Housing inequality $\cdot$ Home-ownership $\cdot$ Poverty $\cdot$ Housing deprivation $\cdot$ Eu-Silc

\title{
1 Introduction
}

Housing well-being is a fundamental need and right: guaranteeing this right still represents a significant challenge in several Member States. At the end of the last decade, the number of households in a severe situation of housing deprivation are estimated to be close to 30 million in 27 European countries (EUROSTAT, 2011). This phenomenon, pointing at social inequality and a risk of poverty is seemingly in contradiction with the extension of home ownership and the spread of a high standard of living. This contradiction is quite illusory because there is a widely confirmed relationship between access to ownership, housing costs and low income (Dewilde, Lancee, 2013; Dewilde, De Decker, 2014). Though around three quarters of Europe's citizens are home owners, the costs of accessing and maintaining a home have continued to rise and cannot only jeopardize housing security and quality, but can also stand in the way of life projects (Palvarini, Pavilion, 2010; Filandri, Olagnero, 2014). More and more in the 2000's "home ownership is not exclusively the preserve of the more affluent and professional classes" (Kennet et al., 2012, p. 14). The market devices supporting the access to ownership, such as mortgages and loans, represent a risk which can have negative effects on the security, wealth and well-being of owners (Boelhouver et al., 2010; Andre et al. 2014). Also the rental system does not, in itself, expose or protect the risk of housing deprivation. It depends on the rules of access (targeted groups or not) and on criteria to give or not support to housing costs of tenants (balance between market price or reduced price rents). Definitively, tenure (considered in the opposition between owners and non owners) is not in itself enough to be predictive of housing deprivation ${ }^{1}$.

In times of crisis, the louse coupling between tenure and housing deprivation increases everywhere, but it is a shared opinion that the depth, breadth and nature of the impact of the crisis vary across societies depending on the congruence of specific risk factors and the social context within which housing policy is shaped and implemented.

As far as housing deprivation is concerned we conform to the approach that stresses on housing inadequacy considered in this case not as a preliminary stage toward homelessness, but as one possible form of social disadvantage (Palvarini, Pavolini, 2010, p. 133).

Housing deprivation is a multidimensional concept tapping different dimensions of housing disease: structural, relational and concerning the overall quality of residential areas (see also further details below). Our interest lies in addressing the presence of quite severe deprivation (two out of three dimensions of deprivation present in the housing experience, and it does not matter which). Nevertheless no doubt exists about the different meanings of being (and accept living) in a crowded dwelling, or in a deprived neighbourhood, or in an unhealthy and uncomfortable apartment. It is important to distinguish them when the question deals with qualitative aspects on, for example, a household's constituents' health. On the contrary it is less relevant when dealing with the general 
housing quality for owners and non owners, with high and low costs; with the balance between economic resources invested and economic results.

In a previous research-study, based on Eu-Silc data referred to Europe-15 and dated 2009 (Filandri, Olagnero, 2014), we showed that, at the end of the last decade, home ownership and housing well being are still strictly associated with resources provided by the family of origin.

In the present paper we aim to verify the general hypothesis that differences in housing deprivation (the reverse of housing well-being) are to be processed taking account the role of the housing costs. Moreover housing costs are a crucial element at both methodological and substantive level in defining poverty. The aim of our analysis is to go more in depth in considering the risk of housing deprivation and its micro and macro conditions in European countries. The framework is represented by the well-known transformations running throughout Europe and concerning the changing rules of accessing ownership.

2 Housing-regime factors, tenure and housing deprivation in an enlarged Europe and in four country clusters

There is much more information on housing tenure than on other housing circumstances. In the broad literature dealing with the housing (regimes, behaviors, etc.) tenure has been the most frequently used indicator to point at differences in the degree of safety, wealth and overall quality connected to the housing experience.

Nevertheless, in times of crisis, the relationship between households and tenure has inevitably created more casualties especially in home ownership, as tenure has expanded.

The tenure types cannot cover the heterogeneity induced in the individual-family positions with regard to housing circumstances. Although housing tenure is still the main characteristic of housing, as reported in research studies about income and poverty, and other large-scale surveys, other macro circumstances can change the situation. As Ida Borg argued: 'the use of tenure types have also been criticized as the concept of tenure has been used too abstractly and too widely and that it overemphasizes just one element in housing systems' (Borg, 2013).

Housing tenure defines the formal position of residents in their capacities as owners, co-owners and users of their dwellings (and thus sets up the rules of the game between actors in the housing market) it has to be supplemented by other indicators. As mentioned above (Borg, 2013), comparative measures based solely on tenure types increase the risk of missing such fundamental differences between housing systems. For example, rents in public housing in Britain are increasingly adjusted towards market levels, while Swedish house builders are building under price control and regulations. The owner-occupied sector in Sweden is therefore claimed to be less relied on market principles than public housing in Britain. According to Borg, it is relevant to distinguish between types and forms of housing tenure, where types of housing tenure refer to broad categories such as renting and forms of housing tenures aim to capture historically specific arrangements across countries, such as tenant-owned housing in Sweden (bostadsrätt), renting directly from British Councils, and housing companies in Finland. Differences in these dimensions may inhibit or enhance the potential of housing as an asset. Borg enumerates macro conditions as including housing markets, housing stock, housing finance and equity release, home building and purchase practices.

Also, within the rental system type important differences of forms are at stake: we want only to mention the famous taxonomy proposed by Kemeny concerning the distinction between dual and unitary rental systems (Kemeny, 1995).

In the present paper, the suggested distinctions in types and forms of housing are used to observe the different performances made at country level as they shape the households' behaviour. 
2.1 The source of heterogeneity and the role of different housing systems in shaping different housing circumstances

The role of housing in welfare regimes has sparked extensive debate. Esping-Andersen's original approach to the process of regulation of social life through welfare regimes paid little attention to housing as an aspect of either the social structure or welfare (Ronald, 2008). Despite their importance related to the actual mediation of welfare, housing systems have historically been considered the 'wobbly pillar' of welfare states (Torgersen, 1987): 'neither fully a part of welfare state nor fully a part of free market, and never provided universal social services like education and health' (Stamsø, 2010).

In contrast to the apparently stable welfare-state configurations that Esping-Andersen (1990) quantify as liberal, conservative, and social democratic welfare regimes, deregulation of housing finance systems has enabled considerable divergence with respect to preferences, incentives, and consumer behaviour, but first of all with respect to objective chance of improving quality of life, being equal to the incidence of housing costs.

A qualitative description of European housing regimes and their transformations in recent decades has been provided by many authors. Norris and Shiels (2007), compare the degree of housing inequality taking into account housing quality, accessibility and affordability over the last few decades, identifying three great country clusters (Northern/Central, Southern and Eastern Europe) More recently Dewilde and De Decker (2014), propose a (somehow shuffled) four clusters typology (see below for details) according to the shared idea (see also Schwartz, Seabrooke, 2008, 2009; Borg, 2013) that we need to break up the black box of housing tenure through the forms and rules of managing the increase of ownership and the residualization of rental systems. The idea is that differences between European housing regimes can be understood, looking at the levels and forms of state intervention versus the role of the market and the family. In fact, models of housing provision reflect political choices influencing access to and characteristics of owning versus renting, influencing in turn the housing outcomes for different social groups.

Therefore, according to the second more recent typology, it's possible to identify at least four clusters of countries according to their housing regime/level of marketization as well as their decommodification and stratification in housing ${ }^{2}$ : a) the 'mortgaged homeownership' regime: where home-ownership levels are high with also high levels of residential mortgage debt; b) 'unitary rental market': with high levels of rent control in both sectors, with a fairly high \% of individuals living in rented housing; c) the 'Southern European countries' regime: with high levels of homeownership, of which a high \% is owned outright, and; d) the 'Eastern European countries' regime: high levels of homeownership, of which a high $\%$ is owned outright and the ratio of housing costs to income is generally low.

As Dewilde and De Decker (2013) argue: "Differences between European housing regimes can be understood in terms of the levels and forms of state intervention versus the role of the market and the family. Models of housing provision result from political choices influencing the access to and characteristics of owning versus renting, influencing in turn the housing outcomes for different social groups"

The sources of increasing heterogeneity of tenure, especially of home ownership, are abundantly recognized in the process by which the access to home-ownership has been strongly stimulated also on account of its being a possible vicarious resource facing the retreat of welfare. Home ownership is already well developed in many countries as an explicit means to supplement or substitute public welfare provision. One important change of housing European backdrop in the early twenty-first century involves the trade off between the potential wealth tied up in owner occupied houses and the chance of facing the weakening of the welfare system and the crisis of the labour market.

Different literature contend the problem concerning the new economic functions of housing market in Europe, especially since the economic crisis. Stephen and Van Steen (2011) recall welfare state literature and housing system literature to affirm that housing not only replicates but sometimes 
contrasts the effect of the welfare state, especially when and where home ownership can compensate the scarcity of resources distributed to the elderly. In the work by Kennet, Forrest and Marsh (2013) the authors say that the potential wealth tied up in owner-occupied housing has been considered, more or less explicitly, to be a solution to the fiscal difficulties involved in the maintenance of welfare commitments, and through that, the advantage of asset-based welfare has frequently become property or housing assets. "Therefore, the household security is argued to have been aggravated by the retreat of collective provision and the individualization of responsibilities" (p. 111).

According to Ronald (2008) many governments have sought to shift responsibility for welfare back onto individuals by encouraging personal saving, investment and asset accumulation. Housing purchase has thus become increasingly seen as a vehicle for, and container of, household asset accumulation with which to protect households against increased risk in the labour market in a context of declining public welfare support" (p. 83).

But, as attractive as asset-based welfare might appear to governments, a number of obstacles have stood in the way of its development (Doling, Ronald, 2010). In regard to whether or not households accumulate housing wealth as part of a long-term strategy, as house prices have increased, the regular savings and costs associated with purchase have moved well beyond the capacity of many households, especially ones with a low income or only one earner.

It is well known that in nations where housing is largely distributed through the market, people with lower incomes, less wealth or less access to credit (typically due to inferior employment positions) will have fewer housing choices. The people who are and have less social and economic resources typically have less desirable or poorer housing conditions than others; will find it harder to enter or be more likely to leave home-ownership; and are more likely to be found in rented tenures (Norris, Winston, 2012).

Dewilde and de Decker (2013) state that in countries with a more marketized housing regime, lowincome households will have less access to 'decent and affordable housing', both in absolute terms and relative to high-income households And more strongly that a stronger trend towards marketization -however conceptualized (in a weak or a strong way) - negatively affects the access to decent and affordable housing for low-income households, both in absolute terms and compared to high-income households.

Moreover, as already observed by Kemeny, in dual rental systems, since targeted social housing provides shelter for people excluded from the regular housing market, the suppliers of social housing may have weak incentives for improving the housing stock available to poor people. The quality of housing can be expected to improve when risks and resources are pooled within a unified system of rental housing, similar to the idea of middle-class inclusion and redistribution of economic resources developed in comparative welfare state research (Korpi, Palme, 1998). Housing deprivation is (or can be) lower in countries with a unitary rental system, where all income groups are subject to the similar principles for rental market regulation. In all these cases, the problem of exclusion is at stake.

However, the focus of our analysis is not on exclusion, but on coping with difficulty stemming from living in a specific regime. In order to analyse the relationship between housing deprivation, tenure and housing regimes, we introduce some variables which are relevant in pointing out the different degrees of social security and economic autonomy of the households: age and income of adult members (being equal family size and structure, presence/absence of work).

3 Household characteristics and housing conditions

3.1 Age effect on tenure and deprivation 
Housing and living arrangements are central aspects of the welfare position of individuals and households. They provide action spaces and dimensions of meaning all through the life course, but with varying emphasis in the different stages of life. The variable "age" is a crucial factor in order to test country differences in treating the risk of housing deprivation over the life course. Young people are supposed to be more exposed to housing deprivation than adults and elderly, according to the life-cycle paradigm, but some targeted measures, market laws, or patterns of intergenerational relationships, can rebalance this difference.

Home ownership is a life-course issue: that is, home ownership increases as people age and achieves higher levels of completion (as indicated by high levels of outright home ownership) among the elderly than among younger adults (Fahey et al., 2004).

As far as the elderly are concerned, the transition to retirement greatly increases the importance of home ownership because the references and daily routines of the world of employment disappear. This is even more the case in advanced age, when restrained physical mobility increasingly makes for a concentration of daily activities in and around the home. According to what has been stated so far, everyday life in old age is above all life at home. Housing thus becomes a primordial concern for the elderly (Kurtz, Blossfeld, 2004; Kohli et al., 2005).

Housing costs are greatest in the early years (mortgage burdens on first-time buyers can consume more than a third of household income) but diminish as the household ages, becoming minimal after the mortgage is paid off. Elderly households can thus survive on a smaller pension, as housing costs are minimal, and use their housing cost to cover the costs of extra welfare needs and possibly care (Toussaint, 2011).

As far as young people are concerned, it has recently been shown that the economic crisis has aggravated the access to ownership especially for those aged 18-34, but also for younger adults outside this age bracket (Lennartz et al., 2014).

Home purchase has become increasingly delayed, requiring long-term strategies and savings plans. And, most of all, large sections of the population of all countries are financially excluded from acquiring housing assets at all so that a property-based system of welfare cannot possibly be fully inclusive of entire national populations (as young people: Lennartz et al., 2014). The extent and life-time distribution of home ownership thus becomes one of the main dimensions of social inequality.

But the housing issue is relevant also from the life transition (and related patterns of intergenerational relationships) point of view. A statement empirically supported by compared research-studies (data ECHP 1994-2001), is that the transition to adulthood increases the risk of economic default when not supported by the family of origin (as well as in Southern Europe) or by the State as in the Northern Europe. In the Southern countries, taking out a mortgage points to support by family nets provided for their youngsters; where the mortgage weighs on the shoulders of an unsupported youngster, the risk of poverty is high (Micheli, 2009).

\subsection{Poverty, tenure and housing cost}

Most of the numerous definitions of poverty and material deprivation cannot be entirely separated from housing circumstances. Housing is a major contributor to income, a source of income-like flow of benefits or even cash income itself, and it makes a big contribution to material living conditions (Fahey et al., 2004; Tunstall et al., 2013).

Poverty rates vary between household types as much if not more than they do between tenures. This means that if not social housing (a sure predictive indicator of poverty as demonstrated by several research studies), renting is neither necessary nor sufficient for identifying poverty: not all renters are living in poverty, and not all people in poverty are renters (Burrows, 2003).

But it is not enough: the reverse is also possible. The welfare safety net for owner-occupiers' mortgage costs has always been more limited than that for social rented tenants' and private rented tenants rental costs. As noted, home-owners do not have access to housing allowances, so poverty 
rates for home-owners with mortgages are very similar in terms of income both before and after housing costs.

Furthermore, not all of those in poverty experience undesirable housing conditions; and yet some people who are not in poverty do experience housing deprivation.

In the wake of these observations some analyses can be recalled. For example, recent research studies focused on poverty by tenure show that people living in poverty are more likely to experience most of the forms of housing quality problems and neighborhood problems than other people, but, that the differences were not always large (Nolan, Wiston 2011; Tunstall et al., 2013). In a market economy, poverty and a low degree of wealth prevent access to many potential housing options, or make them difficult to sustain. People living in poverty generally have worse, and less desirable, housing conditions than those with higher incomes, but they generally avoid housing deprivation.

In general, evidence that poverty affects housing circumstances is stronger than evidence that housing circumstances affect poverty. Nonetheless, it appears that low-cost, decent-quality housing, in an attractive job market, could make a substantial contribution to increasing disposable income, preventing material deprivation and maintaining work incentives.

The focus of interest of our analysis, conversely, is also on the opposite effect: high housing costs can cause poverty and/or housing deprivation. Housing costs constitute the most important and most direct impact of housing on poverty and material deprivation. Not taking housing costs into account means significantly underestimating the risk of poverty and material deprivation for workless households, minority ethnic groups, single people and renters (Fahey et al., 2004; Stephens, van Steen, 2011; Maestri, 2014; Bramley, 2012).

To be deprived or poor is in fact a result of a process. It is dynamic (Leisering, Leibfried, 1999). Thus, poverty can affect people throughout their lives or can emerge after stressful events. Paying high housing costs that outbalance the available resources is a stressful situation potentially leading to poverty.

The number of people in 'housing-cost-induced poverty' (not experiencing poverty until housing costs are taken into account) has increased over the past two decades (EUROSTAT, 2012).

It is sometimes assumed that home-ownership increases incentives for maintaining or even improving quality of housing stock, thus protecting home-owners investment costs. It is possible, but depends on different factors (such as timing of purchase, timing of accumulation or spent income). Overall it is hard to say whether the differences in poverty rate or in the degree of housing deprivation are due to tenure itself or to differences in average incomes over the lifetime.

Therefore, the possible findings showing a positive relationship between the two variables have to be attributed to non-observed heterogeneity.

All in all, it is not in question that direct housing costs, such as rent and mortgages, and other costs of setting up and running a home, take up a large proportion of household budgets. This means that people on low incomes (especially if paying market housing costs and not receiving Housing Benefit) have less income available after paying for housing, and are more likely to experience poverty after housing costs and/or to experience material deprivation than other people on low incomes. Nevertheless, there could be an open question about how housing deprivation originates from economic hardship.

In the scenario presented above, we raise the following research questions:

-How far is tenure predictive of housing deprivation throughout Europe? And how great are the differences among countries? 
-Is there an association between housing costs and tenure? How is the burden of housing costs related to housing deprivation in different types of tenure (ownership/non-ownership), and in different countries?

-Since poverty is a dynamic state, what happens (concerning housing deprivation) to poor households after paying housing cost?

-Is there still the strong divide (Domanski, 2008) between almost all Eastern countries (in which there is both more ownership and more housing deprivation) and "the other Europe"?

In order to answer these questions, we proceed focusing some general hypotheses:

H1. Home-ownership is not a condition sufficient to protect households from housing deprivation: it is no more a privileged condition; moreover, especially in times of crisis, it is actually more exposed to the burden of costs and misses allowances provided to tenants;

$\mathrm{H} 2$. The relationship between tenure and deprivation is mediated by housing costs: owners bear higher housing cost than non-owners. This different burden results in different housing condition (more ownership, higher costs, low deprivation). This is supposed to be sensitive to the age of the members of the household (heavier burden for youngsters, lighter for elderly) and to general varying standards of housing between different country clusters

H3. High housing costs can induce poverty, for both owners and non-owners: the expected effect of housing deprivation in the presence of poverty could not occur; in this case housing deprivation should be considered not only as an outcome of low income, but also as an element in the trade-off with the risk of poverty; it depends on individual and country conditions.

Therefore, taking into account the social and individual circumstances of entering into ownership, different conclusions can be drawn concerning the relationship between tenure, poverty and housing deprivation.

On the basis of the European Union Statistics on Income and Living Conditions ${ }^{3}$ (EU-SILC) a comparative analysis is carried out about housing conditions in Europe by focusing on the relationship among poverty risk, tenure and housing costs. The project database gathers together comparable, cross-sectional and longitudinal multi-dimensional micro-data on income, poverty, social exclusion and living conditions. We used the family data collected in 2011 in this study, as they are the most recent available. Analyses were carried on all European countries.

The study's dependent variables are the housing deprivation, based on the three main dimensions of households' living situation: the space for the number of family members, neighbourhood quality, and housing adequacy. Whether or not space is sufficient was determined by calculating the ratio of number of rooms to number of family members. The deprivation threshold was set at a minimum of one room per person. The quality of the neighbourhood involves the lack of problems associated with noise, crime and pollution. Housing adequacy is given by the amount of natural light (the house is not too dark), whether there is a bath, shower or indoor flushing toilet in the home, and the absence of damp walls and floors, leaking roof and rot in doors and windows.

To provide a synthetic measure, we constructed an additive index. This index was then dichotomized in a variable dummy variable, presence or absence of housing deprivation. We chose to use a single absolute measure for all European countries - in other words, without taking specific national characteristics such as the importance of space in a Northern or Southern country into account - to make immediate comparison possible. All households with two out of three of the indicators presented above were considered to be deprived in terms of housing. The decision to use such a narrow measure was made in accordance with the thesis we wish to demonstrate. If, as we intend to show, the equation home ownership = well-being does not hold, using an overly narrow measure would increase the likelihood of finding situations of deprivation among home owners as 
well as among non-owners. If we find low living standards among owners even when a broad measure is used, we can conclude that our argument is borne out.

The tenure was dichotomized into ownership/non-ownership, without distinguishing between mortgaged and non-mortgaged homes, as whether or not the households observed had entered into a mortgage is linked with the age of the family, the timing of access to ownership, and the level of housing costs that is one of our crucial variable.

Housing costs in EU-SILC database include rent payments, mortgage interest payments, structural insurance, mandatory services and charges, regular maintenance and repairs, taxes and cost of utilities. We use the housing costs ratio relative to disposable household income and we divide it in two, setting the threshold at $30 \%$. In fact usually affordability problems are defined as housing costs greater than or equal to $30 \%$ of disposable housing income, especially for the lowest two income quintiles (Dewilde \& de Decker 2014). We can also call it as objective housing cost burden.

We also consider (in a first step) the income-level of the household. We use the total disposable household income equivalised according to the OECD-modified equivalence scale. We then use the quintile position of the household as control variable in our models.

In a second step we consider the poverty condition of the household. Poverty is defined in relative terms as the proportion of households below $60 \%$ of national median equivalent income. We also consider poverty after deducting housing costs based on a new income threshold calculated after housing expenses (Maestri, 2014). Therefore crossing poverty of disposable income and poverty of disposable income after housing expenses, we obtain 4 situation: a) never poor; b) non poor after housing costs but poor before; c) poor after housing costs but non poor before; always poor.

We investigate the association between the poverty condition, before and after housing costs, and the housing deprivation, taking into account the age of the household. Because the age of the members within the household may vary greatly, we use the age of the highest income earner.

Our other control variables are: the presence of children (none, one, two or more); the number of earners (dual-earner and non dual-earner couples) and, lastly, whether income derives from employment or self-employment (for dual-earner couples we considered income to be from selfemployment if one member in the household is self-employed). We also controlled for the degree of urbanization of the area where the interviewed households live.

The analyses were carried on the whole sample of European households in the EU-SILC dataset.

Notwithstanding the complex relationship between housing condition and welfare provision, comparative research of a larger number of countries is only feasible when some form of classification is used. Based on the classification proposed by Dewilde and de Decker (2014) presented in the previous paragraph, we group our countries in four different housing regimes.

In the analysis we use logistic regression models to estimate the association in a first step between tenure and housing cost with housing deprivation and in a second one between with poverty and housing cost with housing deprivation. To talk into account the differences of context and age we estimated a series of models: one for each combination of country cluster and age group. Every model is specified considering socio-demographic household variables on one hand and the degree of urbanization of the context on the other. Instead of reporting logit coefficients or odds ratios and their level of statistical significance, even though this is a well-established tradition in sociological research, and since in our analysis we compare different cohorts of households in different countries, we estimate the average marginal effects, which allow comparability across groups, are well suited for independent categorical variables and have an easy interpretation because they can be read as average differences in the likelihood of interest between categories.

Table 1 
Our data confirm the hypothesis that home-ownership is associated with better housing conditions throughout Europe, but it is not sufficient to prevent housing deprivation (see also Filandri, Olagnero 2014). In 2011, all four country-clusters home-ownership show decreases in the chance of living in poor housing conditions, even if there is a remarkable proportion of households owning their own home and showing housing deprivation. This last occurrence is more frequent in Southern and Eastern European countries, where home-ownership rate is higher and the market-rules shape the access to it.

Within this common trend, the inter and intra cluster differences are relevant. The smaller inner variance is registered in the first two clusters, even if the UK, due to the Mortgaged homeownership regime, and Sweden due to the Unitary rental market one, are somehow to be considered "outliers" (as we know from Borg's observations, quoted above). The third cluster shows some inner differences: for example Spain has a low level of deprivation, very distinct from Greece and Italy. The most heterogeneous cluster is the Eastern one, especially regarding ownership, where owners live for the most part - one out of four - in poor housing conditions. Also in this case dissimilarity is quite high: the Czech Republic registers barely $13 \%$ of housing deprived households in the group of owners, while Romania has more than $40 \%$. We can easily infer a country-specific, historical "responsibility" in causing the deprivation experienced in this cluster (Domanski, 2008; Lawson et al., 2009). Nevertheless, we must not forget that some Southern European countries are in the same situation. The question is whether it can be caused by the same and/or by other factors than in the Eastern European cluster (home-ownership being widespread in rural zones, etc.).

\section{Table 2}

One of the components that can affect these differences is represented by housing costs. The relationship between tenure and housing cost does not give any clear confirmation of the owners' disadvantage, compared to that of renters. In all European countries, the likelihood of coming under high housing costs (more then $30 \%$ of the total disposable household income) is lower precisely for the owners. This result is indeed not totally "unexpected". Ten years ago, prior to the economic crisis, Fahey, Maitre and Nolan (2004) argued that "house purchase is normally thought to impose heavier financial burdens on households than private renting: it entails both asset acquisition (represented by the repayment of mortgage principal) as well as 'rent' for the use of capital (represented by interest payments), where tenants pay rent only. Yet the most common situation across the 14 countries is that tenants in the private sector pay a larger share of their incomes on rent than do purchasers on mortgage payments" (Fahey et al., 2004, p. 44).

In our case of an enlarged Europe, we have to state that non-ownership is more often a burden than ownership everywhere. The highest percentage of households with a high burden of housing costs on income is in clusters 1 and 2 (Mortgaged home-ownership and Unitary rental market regimes) for renters and in clusters 4 ad 2 (Eastern and Unitary rental market regimes) for home-owners. Of course every country cluster has its own deviant cases: the UK and Norway in cluster 1; the Netherlands in cluster 2; and Greece in cluster 3. The distance between owners and non owners is lower in clusters 3 and 4, when also owners are, for the most part, burdened by housing costs. The hypothesis about a relationship between ownership and the risk of burden seems to be not confirmed but partially in clusters 2 and 4. The difference in incidence of housing costs cannot easily be brought back to the housing regimes.

\section{Table 3}

So far we have figured out that, at least on average, home-ownership shows benefits in terms of better housing conditions and reduced housing costs burden. To better investigate the relationship 
between home-ownership, housing costs and housing deprivation, we have estimated a logistic model designed to calculate housing deprivation by tenure and housing cost burden. We use the age of the household as a stratification variable, because we know that income has a different distribution according to stage of life, as well as the likelihood of being owners and having a mortgage.

Figure 1 shows that the probability of undergoing housing deprivation is, in general, higher for the households (owners or non-owners) with low housing costs.

By looking into the category of owners, we see that households with high housing costs live in better conditions, with the exception of the Mortgaged home-ownership regime, even so, for older households in the Unitary rental market and in the Southern European clusters. Therefore, excluding cluster 1 - Norway, France, Finland, Belgium and the UK - young adults and adults, who own their house, seem to live with better housing conditions if they experience high housing costs relative to their income. The same is true for the non-owners also in the Mortgaged homeownership regime and among the elderly.

\section{Figure 1}

To summarize, some commonalities among country clusters have to be remarked upon. First, low or high housing costs do not seem to matter in getting more or less housing well-being unless ownership is involved. Second, ownership plus high housing costs, is the only condition that guarantees well-being everywhere. Third, elderly people are the most protected age category, everywhere but in the Eastern European housing regime.

And now some differences. Important differences concern the conditions under which, in absence of ownership, housing well being is regardlessly obtained (or deprivation avoided), especially in the last cluster, where no other alternative but ownership with high costs is available to achieve housing well being. Also, age-effect results in some relevant differences: in the first county-cluster the young adult and adult non-owners are the groups most exposed to housing deprivation, both registering low housing costs. The selectivity of the housing system protect neither tenants, nor low housing cost burden households, nor even young adults or adults. In the Unitary rental market cluster, the situation is quite similar to the previous one, with the exception of the higher exposure to deprivation of young owners with low housing costs. In this cluster, ownership does not protect the young people with low expenses on their incomes.

In the Southern Europe 3, the youngsters and adult non-owners with high or low costs are more protected than in the other clusters. This could be explained by different patterns of transition to adulthood and the role of family of origin. Finally, in the Eastern European countries, in contrast to the others, the degree of protection does not appear to increase with increasing of age.

But if the equation "higher housing costs equal better housing conditions" is true, we can speculate whether there is a cumulative disadvantage, linking poverty and deprivation, or, on the contrary, if there is a sort of trade-off where being poor can co-exist with experiencing housing well-being, while, on the contrary, not being poor could associate with housing deprivation.

\section{Table 4}

In answer to this question, we built a typology combining poverty before and poverty after paying housing costs. Four combinations can be obtained: a) never poor; b) non-poor after housing costs but poor before; c) poor after housing costs but non-poor before d) always poor ${ }^{4}$. The most interesting situations we have to look at, in order to investigate the link between poverty and housing costs are the intermediate ones. In table 3 we can observe their distribution in all European countries. The poor after housing cost are more frequent than non-poor after housing cost everywhere with few exceptions: the Netherlands, Cyprus, Romania and the Slovak Republic. 
There are also some countries, where the two rates are similar: France, Norway, Portugal, Italy, Malta, Spain and Poland.

The data are consistent with some previous research studies that point out the relevance of focusing on the burden costs of housing maintenance in studying poverty (Fahey et al., 2004; Stephens, van Steen, 2011; Maestri, 2014).

Actually our aim is to investigate the association between poverty and housing expenses with housing deprivation. Starting from the data that never poor households constantly live in the best housing condition, our focus is on the mismatch between poverty, housing cost and deprivation. In this regard we point to two opposite analytical situations. On the one hand there is the cumulative disadvantage mechanism: being always poor or poor-after-housing costs is associated with housing deprivation. On the other there is the trade-off mechanism: poor after housing cost live in better conditions than always poor and in similar conditions to never poor households. Our data show that the likelihood of the interlacing of poverty and non deprivation does exist everywhere with the exception of the youngsters in the first cluster.

\section{Figure 2}

The idea of the trade-off between poverty and housing deprivation is confirmed as we can observe households which are no more poor from housing costs, but run the risk of housing deprivation. This last circumstance occurs for youngsters and adults in the Unitary rental market regime, for adults in the Mortgaged home-ownership cluster and only for elderly in the Southern European one. On the contrary the trade off is very clear for every age-class in the Eastern European regime.

\section{$7 \quad$ Conclusion and next step of research}

In this paper we have investigated the relationship between tenure, housing costs and poverty as mediated by the housing costs. Our starting idea was to determine whether the huge rise in home ownership in Europe, also in Eastern countries, has been matched by a parallel increase in housing well-being. These two dimensions do not always coincide, but a clear dominance remains. We thus investigate a possible mechanism of this enduring dominance.

Our first hypothesis - that home-ownership does not protect from poverty - is partially disconfirmed, unless we limit the observation to Southern and Eastern Europe, where homeownership rate is higher and the market-rules shape the access to it.

Also, the second hypothesis - the expected association between tenure (ownership) and housing costs burden - has to be better specified looking into the country clusters and explained also taking into account the varying distance between owners and non owners. Unitary rental market and Southern regimes distinguish from the other two (the most unequal) for more uniformity between the two tenures: the first showing the highest housing costs, the second the lowest. We can hardly explain these results without going deeper into housing regime rules and housing standards of the different countries. The relevant differences based on age, and that protection of the elderly is not provided everywhere, warn us not to under evaluate possible age-conflicts.

The third hypothesis about the complex association between housing costs and poverty is widely confirmed. Housing costs can induce poverty, but non poverty after housing cost with housing deprivation is also evident, indicating of a trade-off between poverty and housing deprivation due to coping with economic squeeze. This exchange depends on individual and country-specific conditions. We limit our observations here to the fact that the trade-off is more frequent among youngsters and adults everywhere; it is very clear for every age-class in the Eastern European regime. The divide between Eastern Countries (in which there is both more ownership and more housing deprivation) and 'the other Europe' does still exists, with a degree of variance (here only partially described) that it is worth considering. 


\subsection{Next step of analysis}

The overall results suggest that, in future analyses, we are to be very careful in assuming a total uniformity throughout the Eastern countries cluster ${ }^{5}$. Countries of the old and new Europe can move closer, divide or unify, sometimes breaking the boundaries of well settled typologies (Olagnero et al., 2008, p. 288).

So far we have considered households' chances of facing housing costs burden. A more refined analysis of coping with housing difficulty, including several dimensions, could be carried out. According to Quan \& Hill (2009), we could move forward by considering the complex concept of affordability: purchase affordability, whether a household is able to borrow enough funds to purchase a house; repayment affordability, the burden imposed on a household of repaying the mortgage; income affordability measures the ratio of house prices to income (this last one analysed in our paper). These different abilities and chances are strictly related to both households' and context opportunities and constraints, and are strongly dependent on life course variables. Age of household members is a necessary, but still rough and crude indicator of the relevance of time in shaping the objective and subjective chance to achieve housing well-being. We would like to consider other relevant time dimensions such as the time of entering the house. Thus we could bring to light not only the period-effects, but also the duration-effects, and attempt to link them to differences in the degree of housing safety, housing investment, and related economic and life plans.

\section{Note}

\footnotetext{
${ }^{1}$ We do not use more detailed categories (ownership with mortgage, or outright; rent at market price or at reduced price), because our aim is to focus on home-ownership investigating the effect on housing deprivation stemming from the divide between living in a self-owned house or not.

2 The indicators used for clustering the European countries are: the level of mortgaged and outright homeownership (expressed as a percentage of all homeowners), the size of the social and private rental sector, the ratio of residential mortgage debt to GDP (indicating the marketing of housing finance), and the extent of regulation in both rental sectors based on an index devised by the OECD, the \% of low-income respondents having access to decent and affordable housing, the percentage of individuals in a household experiencing housing costs to be a heavy burden.

3 The EU-SILC project was already under way in 2003 in seven countries (Belgium, Norway, Greece, Luxembourg, Austria, Denmark and Ireland). However, it was only in 2004 that the project was officially launched in fifteen countries (Austria, Belgium, Denmark, Estonia, Finland, France, Greece, Ireland, Italy, Luxembourg, Norway, Portugal, Romania, Spain and Sweden). In 2005, EU-SILC reached its full extension with the twenty-five Member States (EU-25), plus Norway and Iceland.

${ }^{4}$ See Data, Variables and method for mode details.

${ }^{5}$ In previous analyses concerning sociability in Europe 27, the heterogeneity of the Eastern countries emerged. A cluster analysis had shown that Slovenia was closer to the Southern European countries (with the important role of family networks); Estonia, Latvia, Bulgaria, and Romania (a low degree of political participation) were the most distant from all the others; Hungary, Poland, Slovakia, and the Czech Republic represented an intermediate group.
} 


\section{References}

Andre S., Doling J., Lersch P., Wind B, (2014), Acute Housing Finance Problems Before and After the Global Financial Crisis for Homeowners in Europe. Paper for the International Workshop "Home Ownership, Housing Wealth and the Provision of Welfare: Changing Trends, Changing Outcomes?" organised by the ENHR Working Group on Home Ownership and Globalisation, Paris, 15-16 May.

Bramley G. (2012), Affordability, poverty and housing need: triangulating measures and standards, "Journal of Housing and Built Environment", Vol. 27 (27) pp. 133-151.

Boelhouwer P., Doling J., Elsinga M. (eds.) (2010), Home ownership. Getting in, getting from, getting out, Amsterdam IOS Press.

Borg I. (2013), Housing deprivation in Europe. On the role of rental tenure types, Stockholm, Department of Sociology, Swedish University.

Burrows R. (2003), Poverty and home-ownership in contemporary Britain, Bristol, Policy Press.

Dewilde C., De Decker P. (2014), Trends in Housing Inequalities in Europe: What Has Happened and Why Does it Matter, Howcome, Working Paper Series, n. 4.

Dewilde C., Lancee B. (2013), Income Inequality and Access to Housing in Europe, "European Sociological Review", Vol. 29 (6) pp. 1189-1200.

Doling J., Ronald R. (2010), Home ownership and asset-based welfare, "Journal of Housing and Built Environment", Vol. 25 (2) pp. 165-173.

Domanski H. (2008), Housing conditions, in Alber J., Fahey T., Saraceno C. (Eds.), Handbook of quality of Life in the enlarged European union, London, Routledge, pp. 235-253.

EUROSTAT (2011), Housing Conditions in Europe in 2009, "Statistics in Focus" (4).

Fahey T., Maitre B., Nolan B. (2004), Housing expenditure and income poverty in EU countries, “Journal of Social Policy”, 33 (3) pp. 437-454

Ford J., Quilgar D. (2010), Failing home-owners? The effectiveness of public and private safety nets', "Housing Studies", Vol. 16 (2) pp. 147-162.

Filandri M., Olagnero M. (2014), Housing inequality and social class in Europe, in "Housing Studies", Vol. 29 (7) pp. 1-17.

Kemeny P. (1995), From Public to the Social Market. Rental Policy Strategies in Comparative Perspective, London, Routledge.

Kennett P., Forrest R., Marsh A.(2013), The Global Economic Crisis and the Reshaping of Housing Opportunities, "Housing, Theory and Society", Vol. 30 (1) pp. 10-28. 
Kohli M., Künemund H., Zähle T. (2005), Housing and living arrangements, Chapter 2.3 for SHARE First Results Book, January 24.

Kurz, K., Blossfeld, H.P. (2004).,Introduction: Social stratification, welfare regimes, and access to home ownership, in Kurz, K., Blossfeld, H.P. (Eds.), Home ownership and social inequality in comparative perspective, Stanford, Stanford University Press, pp. 1-20.

Lawson J., Haffner M. ,Osley M. (2009), Comparative housing research in the new millenium. Methodological and theoretical contributions from the first decade, Refereed paper presented at the 4th Australasian Housing Researchers Conference, Sydney, 5-7 August, available at http://www.fbe.unsw.edu.au/cf/apnhr/papers/Attachments/Lawson.pdf.

Leisering L., Leibfried S. (1999), Time and Poverty in Western Welfare States, Cambridge, Cambridge University Press.

Lennartz C., Arundel R., Ronald R. (2014), Young People and Home ownership in Europe, through the Global financial crisis, Centre for urban Studies, Working Paper.

Maesti V. (2014), A Measure of Income Poverty Including Housing: Benefits and Limitations for Policy Making, "Social Indicators Research", on line version, 1-22.

Micheli G. (2009), Sempre giovani e mai vecchi, Milano, FrancoAngeli.

Nolan B., Wiston N. (2011), Dimensions of housing deprivation for older people in Ireland, "Social Indicator research", Vol. 104 (3) pp. 369-385.

Norris M., Shiels P. (2007), Housing inequalities in an enlarged European Union: patterns, drivers, implications, "Journal of European Social Policy", Vol. 17 (1) pp. 65-76.

Norris M., Winston N. (2012), Home ownership, housing regimes and income inequalities in Western Europe, "International Journal of Social Welfare", Vol. 21 (2) pp. 127-138.

Olagnero M., Torrioni M.P., Saraceno C. (2008), Patterns of sociability in the enlarged EU, in Alber J., Fahey T., Saraceno C. (Eds.), Handbook of quality of Life in the enlarged European union, London, Routledge, pp. 235-253.

Palvarini P., Pavolini E. (2010), Housing deprivation and vulnerability in Western Europe, in Ranci C. (Eds.), Social vulnerability in Europe. The new configuration of social risks, London, Palgrave McMillan, pp.126-158.

Ronald R. (2008), The Ideology of Home Ownership, London: Palgrave Macmillan.

Schwartz H.M., Seabrooke L. (Eds) (2009), The Politics of Housing Booms and Busts, Basingstoke, Hampshire: Palgrave MacMillan.

Stamso, M. (2010), Housing and welfare policy-changing relations? A cross national comparison, "Housing, Theory and Society", Vol. 27 (1) pp. 64-75.

Stephens M., van Steen G. (2011), Housing poverty and income poverty in England and the Netherlands, "Housing Studies", Vol. 26 (7-8) pp. 1035-57. 
Stone M. (2010), What is housing affordability? The case for the residual income approach, "Housing Policy Debate", Vol. 17 (1) pp. 151-184.

Torgersen U. (1987), Housing: the wobbly pillar under the welfare state, in Turner, B., Kemeny, J., Lundquist, L. (Eds.), Between State and Market: Housing in the Post-industrial Era, Stockholm, Almqvist and Wiksell, pp. 116-126.

Toussaint J. (2011), Housing wealth in retirement strategies: Towards understanding and new hypotheses, Amsterdam, IOS Press.

Tunstall R. et al. (2013), The links between housing and poverty: an evidence review, J.R.F. Report. 


\section{FIGURES}

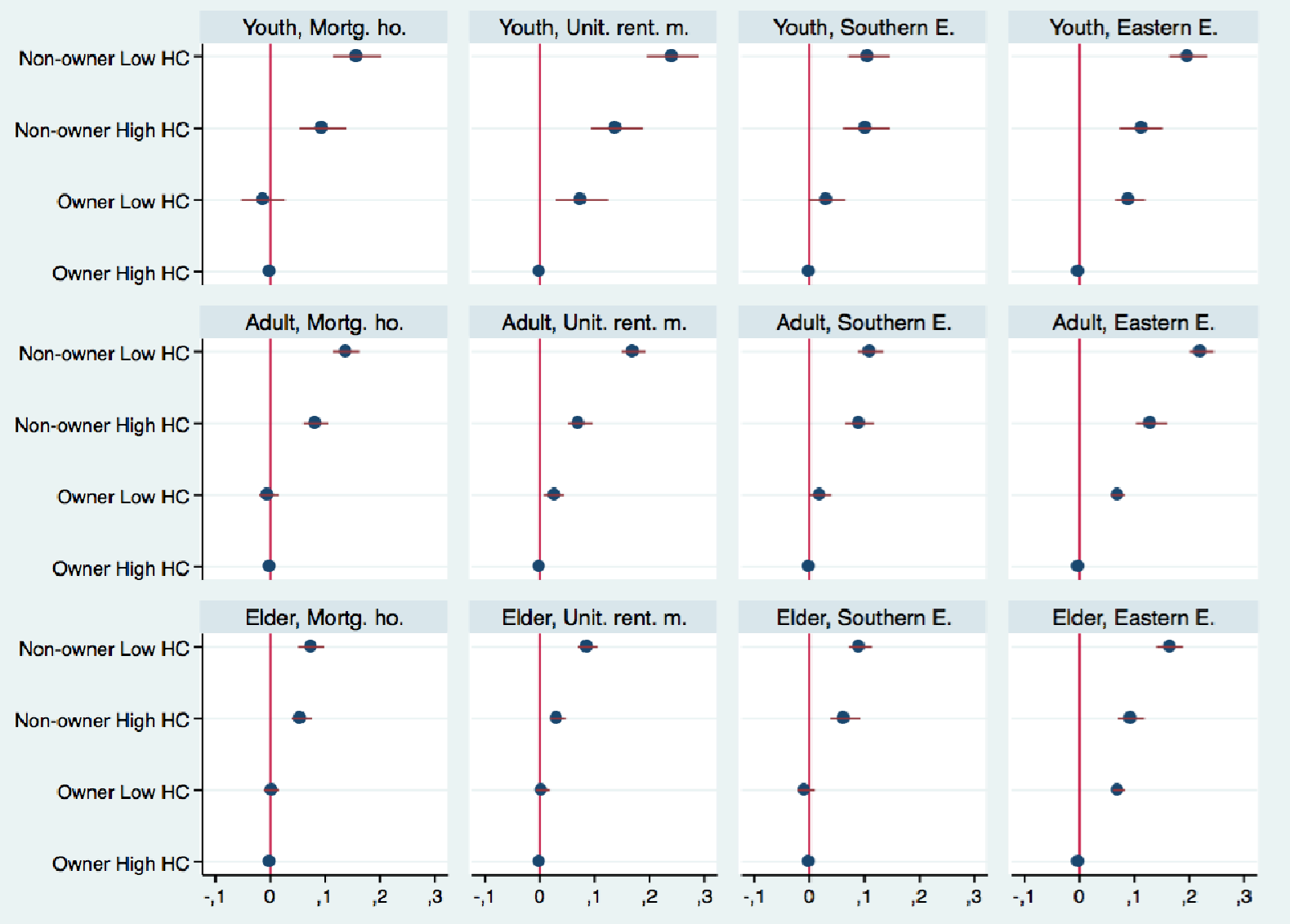

Fig. 1 Logistic regression model of the probability of living with housing deprivation by tenure, housing costs burden and age in Europe: average marginal effects and 95\% confidence intervals. Source EU-SILC 2011

NOTE Models are controlled by the income quintile, the presence of children, the number of earners, the type of earnings, the degree of urbanization 



Fig. 2 Logistic regression model on the probability of living with housing deprivation by poverty before and after taking into account housing cost and age in Europe: average marginal effects and 95\% confidence intervals. Source EU-SILC 2011

NOTE Models are controlled by the income quintile, the presence of children, the number of earners, the type of earnings, the degree of urbanization 
TABLES

Table 1

\begin{tabular}{|c|c|c|c|c|}
\hline Cluster & Country & $\begin{array}{l}\text { Home- } \\
\text { ownershio } \\
\text { rate }\end{array}$ & $\begin{array}{c}\text { Housing } \\
\text { cost } \\
\text { burden } \\
\text { over } \\
30 \% \\
\end{array}$ & Sample size \\
\hline \multirow{5}{*}{$\begin{array}{c}\text { Mortgaged } \\
\text { homeownership }\end{array}$} & Belgium & 70,2 & 23,9 & 5.660 \\
\hline & Finland & 76,7 & 14,7 & 8.975 \\
\hline & France & 64,8 & 17,1 & 10.882 \\
\hline & Norway & 84,7 & 17,7 & 4.442 \\
\hline & UK & 71,1 & 37,1 & 7.687 \\
\hline \multirow{5}{*}{$\begin{array}{l}\text { Unitary rental } \\
\text { market }\end{array}$} & Austria & 52,4 & 15,2 & 5.939 \\
\hline & Denmark & 73,4 & 35,6 & 5.070 \\
\hline & Germany & 51,0 & 38,1 & 12.915 \\
\hline & Sweden & 69,6 & 18,3 & 6.425 \\
\hline & the Netherlands & 71,8 & 37,8 & 10.012 \\
\hline \multirow{6}{*}{$\begin{array}{l}\text { Southern } \\
\text { European }\end{array}$} & Cyprus & 69,1 & 6,4 & 3.759 \\
\hline & Greece & 80,2 & 50,1 & 5.787 \\
\hline & Italy & 75,4 & 12,8 & 18.623 \\
\hline & Malta & 76,2 & 6,0 & 3.912 \\
\hline & Portugal & 75,8 & 10,3 & 5.510 \\
\hline & Spain & 83,4 & 16,4 & 12.570 \\
\hline \multirow{10}{*}{$\begin{array}{l}\text { Eastern } \\
\text { European }\end{array}$} & Bulgaria & 87,6 & 25,8 & 6.290 \\
\hline & Czech republic & 79,4 & 27,0 & 8.510 \\
\hline & Estonia & 83,8 & 13,0 & 4.792 \\
\hline & Hungary & 88,5 & 33,3 & 11.217 \\
\hline & Latvia & 82,5 & 26,9 & 6.170 \\
\hline & Lithuania & 94,8 & 19,5 & 4.991 \\
\hline & Poland & 81,4 & 25,3 & 12.073 \\
\hline & Romania & 97,4 & 21,9 & 7.367 \\
\hline & Slovak Republic & 91,0 & 18,5 & 4.992 \\
\hline & Slovenia & 81,9 & 8,8 & 8.877 \\
\hline \multicolumn{2}{|c|}{ Mortgaged homeownersh } & 72,1 & 21,7 & 37.646 \\
\hline \multicolumn{2}{|c|}{ Unitary rental market } & 62,1 & 31,2 & 40.361 \\
\hline \multicolumn{2}{|c|}{ Southern European } & 77,6 & 16,7 & 50.161 \\
\hline \multicolumn{2}{|l|}{ Eastern European } & 86,1 & 22,9 & 75.279 \\
\hline
\end{tabular}

Source: EU-SILC 2011

Table 2 Housing deprivation by tenure in Europe

\begin{tabular}{clrr}
\hline Cluster & \multicolumn{1}{c}{ Country } & Owner & Non-owner \\
\hline & Finland & 4,8 & 20,2 \\
Mortgaged & Norway & 5,7 & 19,5 \\
homeownership & France & 8,5 & 26,7 \\
& UK & 11,5 & 26,9 \\
& Belgium & 11,6 & 25,8 \\
\hline \multirow{4}{*}{ Unitary rental market } & Germany & 8,4 & 24,2 \\
& Sweden & 9,0 & 22,5 \\
& Austria & 10,5 & 23,8 \\
& the Netherlands & 10,5 & 16,6 \\
& Denmark & 11,1 & 24,9 \\
\hline
\end{tabular}




\begin{tabular}{clrr} 
& Spain & 9,3 & 17,9 \\
& Malta & 12,4 & 24,0 \\
Southern European & Portugal & 14,3 & 31,0 \\
& Cyprus & 20,5 & 21,6 \\
& Italy & 22,8 & 34,0 \\
& Greece & 23,9 & 32,8 \\
\hline & Czech republic & 13,3 & 28,4 \\
& Lithuania & 16,9 & 35,5 \\
& Slovak Republic & 17,9 & 30,6 \\
& Poland & 20,1 & 42,3 \\
Eastern European & Estonia & 20,9 & 26,6 \\
& Hungary & 25,0 & 40,6 \\
& Slovenia & 30,6 & 39,0 \\
& Latvia & 36,4 & 56,8 \\
& Bulgaria & 36,5 & 45,8 \\
& Romania & 43,1 & 55,2 \\
\hline Mortgaged homeownership & 8,2 & 24,8 \\
Unitary rental market & & 9,8 & 22,6 \\
Southern European & & 17,4 & 28,4 \\
Eastern European & & 26,2 & 39,4 \\
\hline Source: EU-SILC 2011 & &
\end{tabular}

Source: EU-SILC 2011

Table 3 Housing cost over 30\% of total disposable household income by tenure in Europe

\begin{tabular}{clrr}
\hline Cluster & \multicolumn{1}{c}{ Country } & Owner & Non-owner \\
\hline & Norway & 14,2 & 37,2 \\
Mortgaged homeownership & France & 1,8 & 45,2 \\
& Finland & 4,6 & 48,0 \\
& Belgium & 8,9 & 59,1 \\
& UK & 21,7 & 75,0 \\
\hline \multirow{4}{*}{ Unitary rental market } & Austria & 6,1 & 25,1 \\
& Sweden & 8,2 & 41,5 \\
& Germany & 25,2 & 51,6 \\
& the Netherlands & 30,3 & 56,6 \\
& Denmark & 26,2 & 61,4 \\
\hline \multirow{3}{*}{ Southern European } & Malta & 5,1 & 8,8 \\
& Cyprus & 3,7 & 12,6 \\
& Portugal & 6,7 & 21,5 \\
& Italy & 6,0 & 33,6 \\
& Spain & 10,9 & 44,4 \\
& Greece & 46,8 & 63,5 \\
\hline \multirow{3}{*}{ Eastern European } & Slovenia & 7,0 & 17,1 \\
& Estonia & 11,9 & 18,6 \\
& Slovak Republic & 18,2 & 21,5 \\
& Lithuania & 19,0 & 29,3 \\
& Latvia & 25,8 & 31,9 \\
Snitary rental market & Poland & 23,0 & 35,5 \\
& Bulgaria & 24,3 & 36,5 \\
& Czech republic & 21,8 & 46,8 \\
& Hungary & 31,3 & 48,8 \\
& Romania & 21,1 & 50,0 \\
\hline European & & 9,3 & 53,8 \\
& & 21,4 & 47,2 \\
& & 12,0 & 33,0
\end{tabular}


Source: EU-SILC 2011

Table 4 Rate of poor and non-poor households after housing cost in Europe

\begin{tabular}{|c|c|c|c|}
\hline Cluster & Country & $\begin{array}{c}\text { Poor after } \\
\text { housing cost }\end{array}$ & $\begin{array}{c}\text { Non-poor after } \\
\text { housing cost }\end{array}$ \\
\hline \multirow{5}{*}{$\begin{array}{c}\text { Mortgaged } \\
\text { homeownership }\end{array}$} & Belgium & 9,6 & 3,9 \\
\hline & Finland & 8,3 & 5,3 \\
\hline & France & 7,2 & 7,8 \\
\hline & Norway & 7,3 & 7,7 \\
\hline & UK & 12,3 & 6,1 \\
\hline \multirow{5}{*}{$\begin{array}{l}\text { Unitary rental } \\
\text { market }\end{array}$} & Austria & 6,2 & 5,0 \\
\hline & Denmark & 10,7 & 1,9 \\
\hline & Germany & 10,0 & 4,6 \\
\hline & Sweden & 9,7 & 1,0 \\
\hline & the Netherlands & 8,3 & 12,9 \\
\hline \multirow{6}{*}{$\begin{array}{l}\text { Southern } \\
\text { European }\end{array}$} & Cyprus & 4,0 & 7,6 \\
\hline & Greece & 10,5 & 1,6 \\
\hline & Italy & 5,6 & 4,8 \\
\hline & Malta & 4,4 & 4,4 \\
\hline & Portugal & 5,2 & 5,8 \\
\hline & Spain & 5,8 & 4,8 \\
\hline \multirow{10}{*}{$\begin{array}{l}\text { Eastern } \\
\text { European }\end{array}$} & Bulgaria & 8,6 & 5,1 \\
\hline & Czech republic & 9,6 & 6,4 \\
\hline & Estonia & 5,4 & 3,0 \\
\hline & Hungary & 8,7 & 6,9 \\
\hline & Latvia & 7,7 & 5,2 \\
\hline & Lithuania & 7,3 & 6,0 \\
\hline & Poland & 7,5 & 6,6 \\
\hline & Romania & 9,0 & 21,0 \\
\hline & Slovak Republic & 6,4 & 7,3 \\
\hline & Slovenia & 5,7 & 3,0 \\
\hline \multicolumn{2}{|c|}{ Mortgaged homeownersh } & 8,8 & 6,2 \\
\hline \multicolumn{2}{|c|}{ Unitary rental market } & 9,1 & 5,2 \\
\hline \multicolumn{2}{|c|}{ Southern European } & 5,9 & 4,7 \\
\hline \multicolumn{2}{|l|}{ Eastern European } & 7,7 & 7,8 \\
\hline
\end{tabular}

Source: EU-SILC 2011 